of Georgia. Journal of Asian Earth Sciences. 2018. Vol. 156. pp. 226-245.

17. Yetirmishli G. J., Mammadli T. Y, Kazimova S. E. Features of seismicity of Azerbaijan part of the Greater Caucasus. Journal of Georgian Geophysical Society. Iss. A. Physics of Solid Earth. 2013. Vol. 16a. pp. 55-60.

18. Yusubov N. P., Guliev I. S. Seismological model of a mud volcano system. Azerbajdzhanskoe neftyanoe khozyajstvo. 2011. No. 3. pp. 12-20.

19. Mammadli T. Y. Seismogenic zones of Azerbaijan and their depth structural features. Geologiya i geophysika Yuga Rossii. 2012. No. 3. pp. 54-64.

20. Aliyev Ad. A., Guliyevl. S., Dadashov F. H., Rahmanov R. R. Atlas of the world mud volcanoes. Baku : Nafta-Press, 2015. $322 \mathrm{p}$

21. Aliev A. A. Mud volcanism of the South Caspian oil-and-gas basin. Geologiya i mineralnye resursy Mirovogo okeana. 2006. No. 3. pp. 35-51.

22. Rachinsky M. Z., Kerimov V. Yu. Fluid dynamics of oil and gas reservoirs. Scientific Editor M. V. Gorfunkel. Scrivener Publishing, USA, 2015. $622 \mathrm{p}$.

23. Reilinger R., McClusky S., Vernant P., Lawrence S., Ergintav S. et. al. GPS constraints on continental deformation in the Africa-Arabia-Eurasia continental collision zone and implica- tions for the dynamics of plate interactions. Journal of Geophysical Research: Solid Earth. 2006. Vol. 111(B5)

24. Guliev I. S., Kerimov V. Yu., Mustaev R. N. Fundamental Challenges of the Location of Oil and Gas in the South Caspian Basin. Doklady Earth Sciences. 2016. Vol. 471, Part 1. pp. 1109-1112.

25. Guliyev I. S., Feizullayev A. A. All about Mud Volcanoes. Baku : Nafta-Press, 1997.

26. Guliyev I. S., Kerimov V. Yu., Mustaev R. N., Bondarev A. V. The Estimation of the Generation Potential of the Low Permeable Shale Strata of the Maikop Caucasian Series. SOCAR Proceedings. 2018. No. 1 pp. 4-20.

27. Guliyev I. S., Kerimov V. Yu., Osipov, A. V., Mustaev R. N. Generation and accumulation of hydrocarbons at great depths under the earth's crust. SOCAR Proceedings. 2017. Vol. 1. pp. 4-16.

28. Kerimov V. Yu., Rachinsky M. Z. Geofluid dynamic concept of hydrocarbon accumulation in natural reservoirs. Doklady Earth Sciences. 2016. Vol. 471, No 1. pp. 1123-1125.

29. Kerimov V. Yu., Gordadze G. N., Lapidus A. L., Giruts M. V., Mustaev R. N. et al. Physicochemical Properties and Genesis of the Asphaltites of Orenburg Oblast. Solid Fuel Chemistry. 2018. Vol. 52(2). pp. 128-137.

30. Kerimov V. Yu., Mustaev R. N., Osipov A. V. Peculiarities of Hydrocarbon Generation at Great Depths in the Crust. Doklady Earth Sciences. 2018. Vol. 483(1). pp. 1413-1417.

UDC 553.41

A. V. SNACHEV ${ }^{1}$, Head of Laboratory, Candidate of Geologo-Mineralogical Sciences, SAVant@rambler.ru

A. V. KOLOMOETS ${ }^{2}$, Senior Lecturer

M. A. RASSOMAKHIN ${ }^{3}$, Junior Researcher

V. I. SNACHEV ${ }^{1}$, Professor, Doctor of Geologo-Mineralogical Sciences

${ }^{1}$ Institute of Geology, Ufa Federal Research Center, Russian Academy of Sciences, Ufa, Russia

${ }^{2}$ Orenburg State University, Orenburg, Russia

${ }^{3}$ South Urals Federal Research Center of Mineralogy and Geoecology, Russian Academy of Sciences, Miass, Russia

\title{
GEOLOGY AND GOLD CONTENT OF CARBONACEOUS SHALE IN BAIKAL MINERALIZATION SITE, SOUTHERN URAL
}

\section{Introduction}

Black shale sediments are widely spread worldwide. They represent a very favorable geochemical environment for the primary chemical adsorption of noble and rare metals and are the source of such metals during metamorphic alteration [1-6]. Black shale sediments are associated with gold deposits in the world and in the Southern Ural [7-10]. In the Orenburg Region of the Southern Ural, gold-bearing ore occurs in carbon deposits of Kumak ore field adjoining the Anikhovsky Graben of the East Ural Uplift. Here, a score or two gold ore deposits were discovered (East Tykasha, Kommercheskoe, Zabaikal, Baikal, Tsentralnoe, Kumak, Kumak South, etc.). Numerous exploration and geological studies accomplished in this area within nearly a century enabled adjustment of the ore field geology, as well as the metallogeny imaging and reconstruction of deposition of sediments [7, 11-14].

The key objectives of this study are examination of carbon deposits in Baikal mineralization site, assessment of their gold content, and specification of features of noble-metal
The authors analyze gold mineralization in Baikal site inside Kumak ore field, adjoined to Bredin black shale sediments (C1bd). It is found that the gold mineralization within the site adjoins mostly bands of quart-micaceous-tourmaline metasomatically altered carbonaceous shale. Float sampling of all local rock varieties shows commercial content of gold (to $6.5 \mathrm{~g} / \mathrm{t}$ ) and stable high content of silver (to $7.6 \mathrm{~g} / \mathrm{t}$ ). Gold is mostly finely dispersed, and is connected with two basic mineral associations: gold-bismuth-telluride and native gold intergrown with tourmaline. The analysis of compositions of gold particles reveals their high carat type. Chemically, tourmaline belongs to dravite and foitite, and is similar to tourmaline from the deposits of orogenic gold and goldbearing sulfide ores. Tight accretion of fine needle-like tourmaline and gold implies their synchronous formation, and allows assessing Baikal site as the quartz-tourmaline gold ore formation.

Keywords: Southern Ural, Kumak ore field, Baikal ore site, carbonaceous shale, black shale, noble metals, gold, silver, telluride, tourmaline.

DOI: $10.17580 / \mathrm{em} .2021 .01 .02$ 
and gold-tourmaline mineralization widespread in enclosing rock mass. To this effect, in 2018-2020 the authors have carried out field the works and analyses to refine some controversial issues concerned with history of the ore site under discussion.

\section{Research techniques}

Noble metals were assessed at the laboratory of Orenburg Diversified Company (Orenburg, executive A. I. Korchagina). Gold content was estimated by atomic absorption and extraction using organic sulfides (NSAM 237-S procedure, measurement range $0.10-20 \mathrm{~g} / \mathrm{t}$ ), and silver content was determined by flame atomic absorption (NSAM 130-S procedure, measurement range 2-2000 g/t, spectrophotometer S-115, flame photometric analyzer PAZH-1, photoelectric colorimeter KFK-2).

Surface imaging of gold grains and microprobe analysis of polished sections were implemented using scanning electron microscope Tescan Vega 3 with energy dispersive spectrometer Oxford Instruments X-act at the Sharing Center affiliated with the South Urals Federal Research Center of Mineralogy and Geoecology, Russian Academy of Sciences (analyst M. A. Rassomakhin, carbonaceous coating, boosting voltage $20 \mathrm{kV}$, net time $120 \mathrm{~s}$, reference standards - courtesy MicroAnalysis Consultants LTD, Registration No. 1362).

\section{Geological structure of study area}

The test gold ore body adjoins the Bredin carbon-carbonate-terrigene series $\left(C_{1} b d\right) 2$ kilometers north of Kumak field (Fig. 1). The geological profile of the series is dominated with carbon-bearing terrigene sediments: siltstone, carbonaceous-clayey shale and sandstone, which form a thick ore host band $70-140 \mathrm{~m}$ wide and $20 \mathrm{~km}$ long (Fig. 2). At the bottom of the profile, some effusive dacite and andesite porphyritic and tuff rocks occur. The Bredin series age is determined from the estimates of foraminifers in limestone interbeds, remnant microfauna and spores of old fern, calamite and other plants. Extensive $\mathrm{N}-\mathrm{S}$ and nearly $\mathrm{N}-\mathrm{S}$ faulting is observed in the site. Faulting is represented by schistosity, associate shear zones and quartz reefs. At a great depth, carbonaceous shale is broken by an intrusion of Kumak diorite $\left(\delta C_{1} k\right)$ lengthwise the entire ore zone.

Depending on the composition and ratio of the components, black shale rocks can be divided into sericitic-quarztocarbonaceous, quartzo-carbonaceous-tourmaline, ottrelitecarbonaceous and quartzo-carbonaceous-ottrelite species. Sericitic-quartzo-carbonaceous black shale is spread to the widest extent, and represents grayish black and sometimes black finely grained, weakly schistous rock. High goffering is governed by elongated quartz and tourmaline grains, as well as by mica flakes, laths and scale aggregates. The texture is conditioned by inconsistent-width bands of mostly quartz and mica with carbonaceous substance. Black shale mineralogy is represented by quartz (to $40 \%$ ), sericite (5-10\%), carbonaceous substance (to $50 \%$ ), carbonate (5-10\%) and sulfides (to $5 \%$ ). Muscovite and chlorite are present in an insignificant amount. Accessory minerals are zircon, rutile, apatite, ilmenite, baddeleyite, as well as a variety of rare earths (monazite, xenotime, bastnasite, Ce-rhabdophanite).

Carbonaceous substance represents large veins and flakes of graphite or finely dispersed graphite particles, which gives the rock a dark grey color (up to black). Isotopic composition

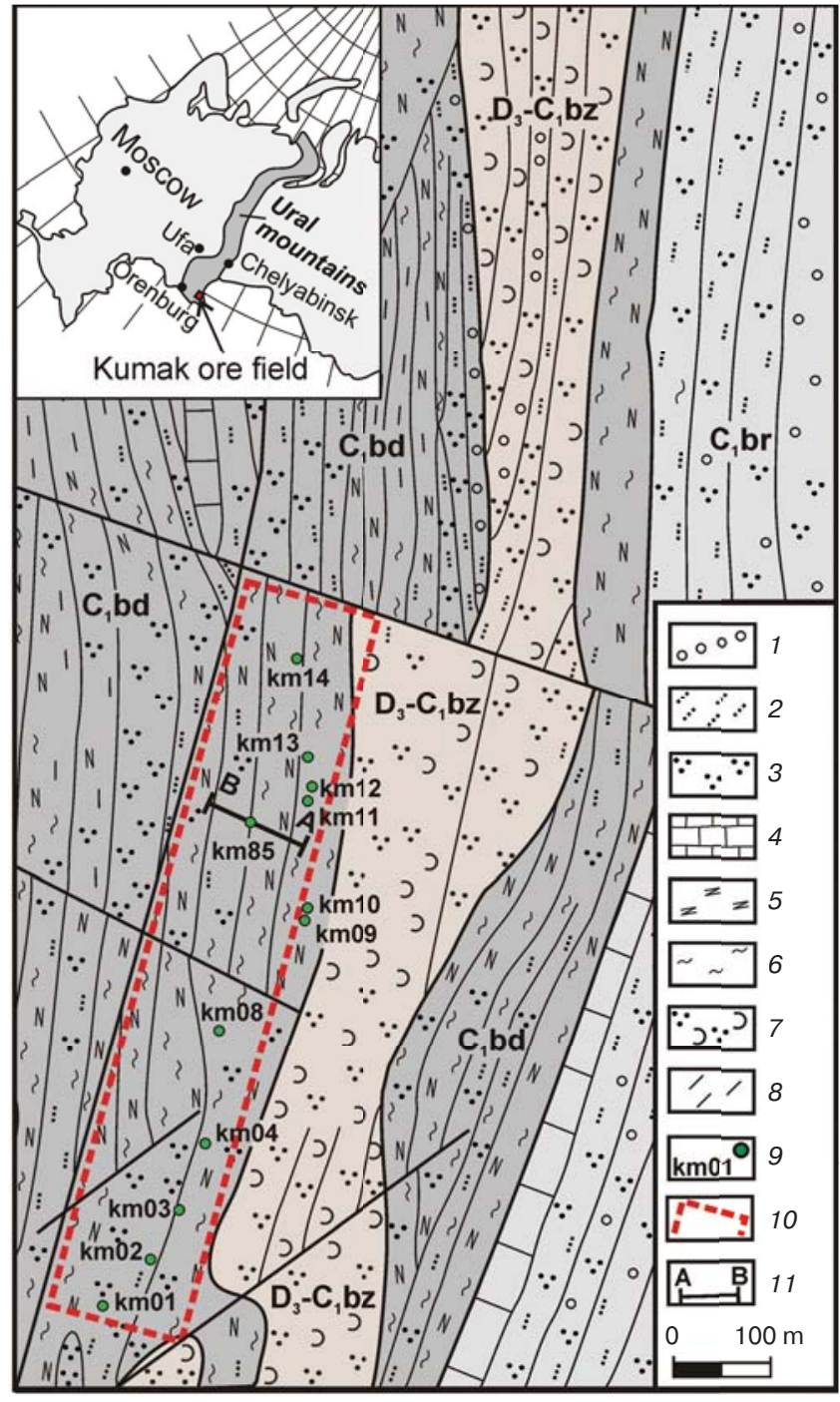

Fig. 1. Geological map of Baikal ore site (by E. E. Mironov, with authors' simplification)

1 - conglomerates, 2 - sandstone, 3 - siltstone, 4 - limestone, 5 carbonaceous shale, 6 - sericitic shale, 7 - tuffite, tuffaleurolite and tuffsandstone; 8 - green clayey shale; 9 - float sampling; 10 mineralization outline; 11 - delve position

of carbon $\delta^{13} \mathrm{C}$, as against PDB standard, ranges from (-19.07) to $(-22.80)$ and points at biogenicity of carbon [15]. The average content of $\mathrm{C}_{\text {org }}$ in shale is $6.4 \%$ (maximum $11.1 \%$ ), owing to which this is carbonaceous shale. The thermo-gravimetric analysis of Bredin carbonaceous deposits shows that organic carbon is highly metamorphized to a rank coincident with the epidote-amphibole sub-facies of greenschist facies [15].

Petrochemically, Bredin series black shale falls within the fields of terrigene-carbonaceous and silica-carbonaceous formations in the standard diagram. Deposition conditions were very specific for the deposits of the Southern Ural. Terrigene and highly aluminous sediments experienced minimum portage and were mainly generated from broken base rocks and erosion products of acidic vulcanite at the bottom of the geological profile. Sedimentation occurred in transition from rifting to collision situation in geodynamics. 


\section{A $\stackrel{\text { Azimuth } 310^{\circ}}{\longrightarrow}$}
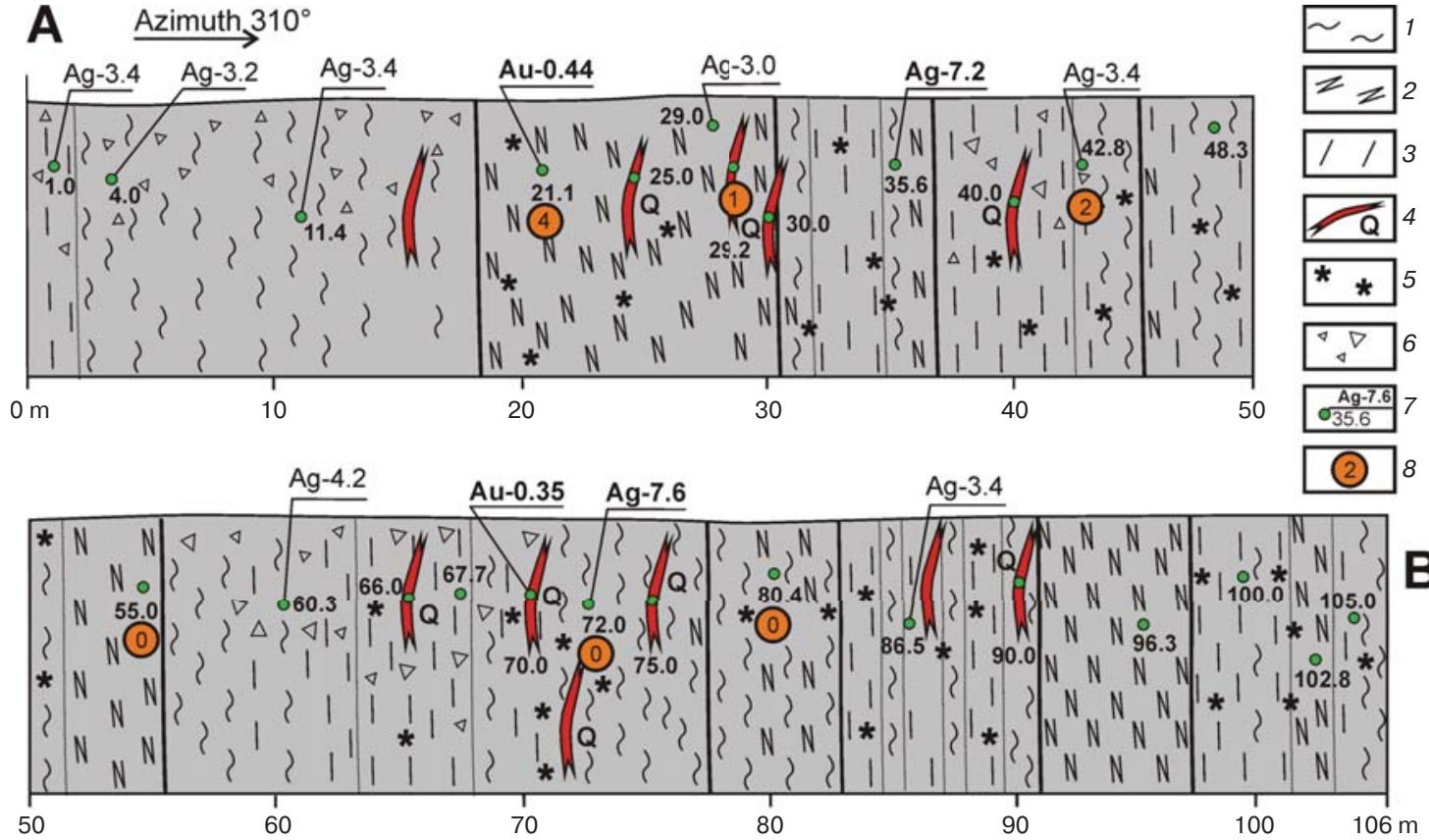

Fig. 2. Sketch of delve wall and noble metals; sampling scheme A-B (see Fig. 1):

1 - sericitic shale; 2 - black carbonaceous shale; 3 - clayey and green shale, 4 - quartz veins, 5 - ferruginous rocks, 6 - landwaste-rubble residuum; 7 - sampling points and significant contents of Au and Ag, 8 - panning sampling points and number of washed gold particles

\section{Ore content of carbonaceous shale}

Kumak field features a variety of gold ore mineralization and complex poly-formation mineralization [7] mostly adjoined to bands of quartzo-micaceous-tourmaline metasomatically altered carbonaceous shale. The alteration represents sericite ribbons, recrystallization and segregation of quartz into different thickness veins and strings, tourmalinization, development of carbonate and ferruginization. Rich ore zones are traced at the intersections of the N-S Eastern Anikhovsky Faults and branching disturbed fractures of the N-E and N-W orientation [14].

In archive documents and in publications, the data on mineral associations widely spread in ore, and on associate minerals of gold are scarce and ambiguous. Four mineral associations contain gold [13]. The first association occurs in the south of the study ore field (Kumak ore body and Baikal site) and represents a gold-bismuth-telluride mineralization (Fig. 3, No. 3; Table 1), as well as inclusions of rucklidgeite and native gold in cobalite (Fig. 3, No. 2). The second association is fine native gold (films and nests) observed in all kinds of shale and in quartz and scheelite-quartz veins (Fig. 4). The third association is poly-metal mineralization with low content of noble metals (this association weakly shows itself in
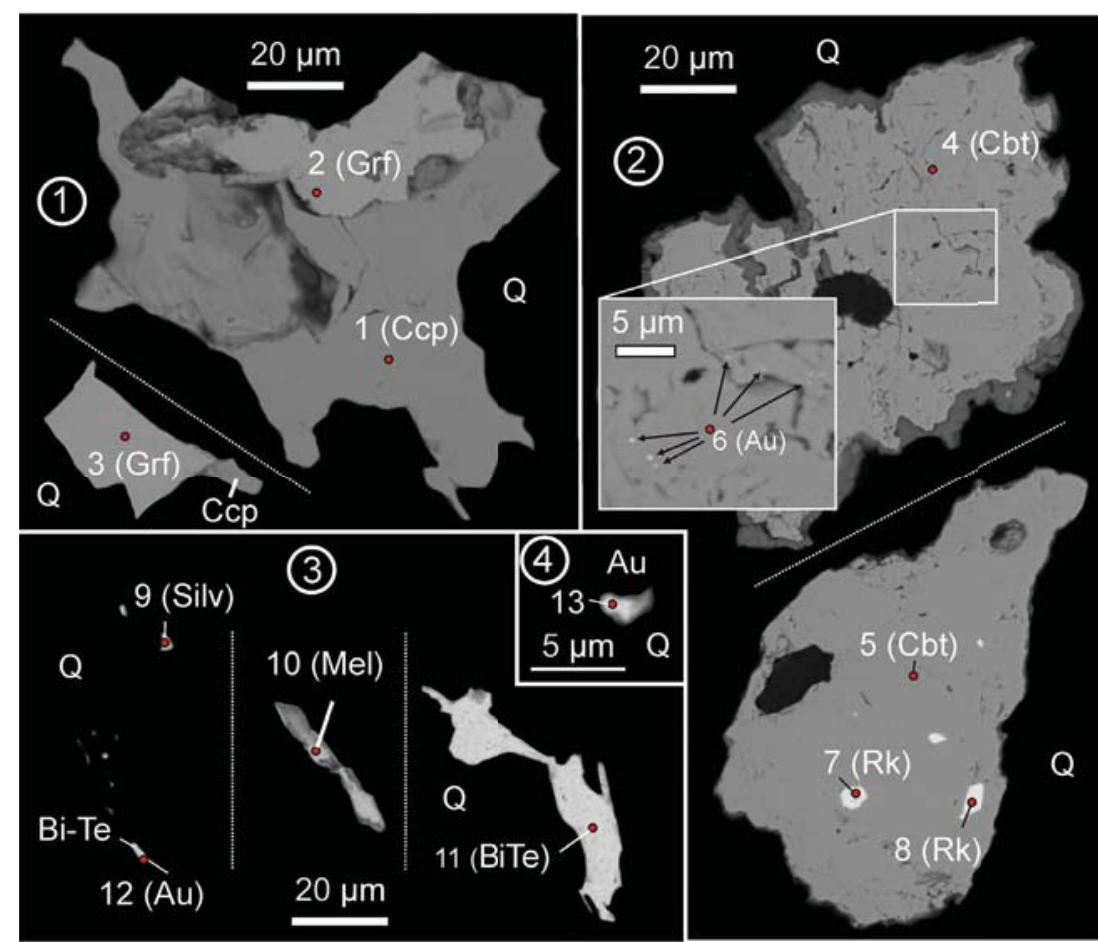

Fig. 3. Submicroscopic images of mineral inclusions in carbonaceous shale in Baikal site:

1 - accretion of chalcopyrite (Ccp) and gersdorffite (Grf); 2 - grains of cobaltite (Cbt) with inclusions of native gold $(\mathrm{Au})$ and rucklidgeite $(\mathrm{Rk}) ; 3$ - accretion of indefinite bismuth telluride $(\mathrm{Bi}-\mathrm{Te})$ with gold $(\mathrm{Au})$, nickel telluride (melonite, Mel), bismuth telluride (tellurobismuthite, BiTe) and gold (sylvanite, Silv); 4 - native gold (Au) in quartz (Q) 
the study area). The dominant fourth association is traced in the main shear zone in the north. Gold is finely dispersed here, is associated with fine crystals of pyrite and with arsenopyrite, and adjoins zones of abundant tourmalinization.

Tourmaline in Baikal site is observed as idiomorphic crystals, features green pleochroism, is nonuniformly developed in rocks and prevails in the intervals rich with carbonaceous substance (Fig. 5a). It is rarely found in quartz-mica interbeds (Fig. 5b), and its elongated prismatic crystals are curved in the longitudinal sections. Tourmaline in the longitudinal sections is represented by thin and elongated narrow-prismatic crystals to $0.8 \mathrm{~mm}$ in size, often with fissures; in the lateral sections - by various hexagons. Fissures in tourmaline crystals (closed or slightly open) are reflective of brittle deformation of tourmaline. Sometimes, in the kinks of folds nearby open fissures, plastic deformation of tourmaline is revealed in the slight bending of crystals. Crystals often show zonal structure of tourmaline, accentuated by the mineral color: bluish green in the center and light green in the periphery (Fig. 5c). High objective magnification allows observing some few poikilitic inclusions of carbonaceous substance. Chemically, Baikal site tourmaline falls within the field of dravite, foitite and schorl (Table 2, Fig. 5j). This tourmaline is high-magnesia, free from impurities of metals, $\mathrm{Mn}, \mathrm{F}$ and As typical of tourmaline from porphyrite and granite deposits [16-18], and is similar to metamorphogene dravite from orogenic gold and gold-sulfide deposits as well as to tourmaline from gold-porphyritic bodies [18-22].

The prevailing tight intergrowth of needle-shaped tourmaline and gold implies their synchronous deposition. This fact allowed M. N. Albov to delineate a gold-bearing quartzotourmaline formation within Kumak ore field [12]. Considering specific chemical composition of tourmaline and its occurrence at sericitequartzo-carbonaceous shale, Serdyuchenko's model of tourmaline forming seems assumable [23]. In this model, first, primary deposition of boron took places in old marine sand and clay sediments; then, during regional or contactregional metamorphism, rock experienced partial recrystallization, and boron migrated and deposited in quartzo-sericitic strings and carbonaceous shale $[24,25]$.

In the center of Baikal site, we described and assayed a delve which totally exposed the oreenclosing black shale belt (see Fig. 2). Float sampling of all rock varieties along the cross-section and across the area of the ore body showed commercial gold content to $6.5 \mathrm{~g} / \mathrm{t}$ (Table 3) stable high silver content to $7.6 \mathrm{~g} / \mathrm{t}$ (Table 4). Considering extremely nonuniform content of gold in ore bodies, we additionally washed panning concentrate samples taken from carbonaceous shale and residuum composed mainly of landwaste and veined quartz and carbonaceous shale debris, as well as examined crushed samples (see Fig. 2). All in all, we

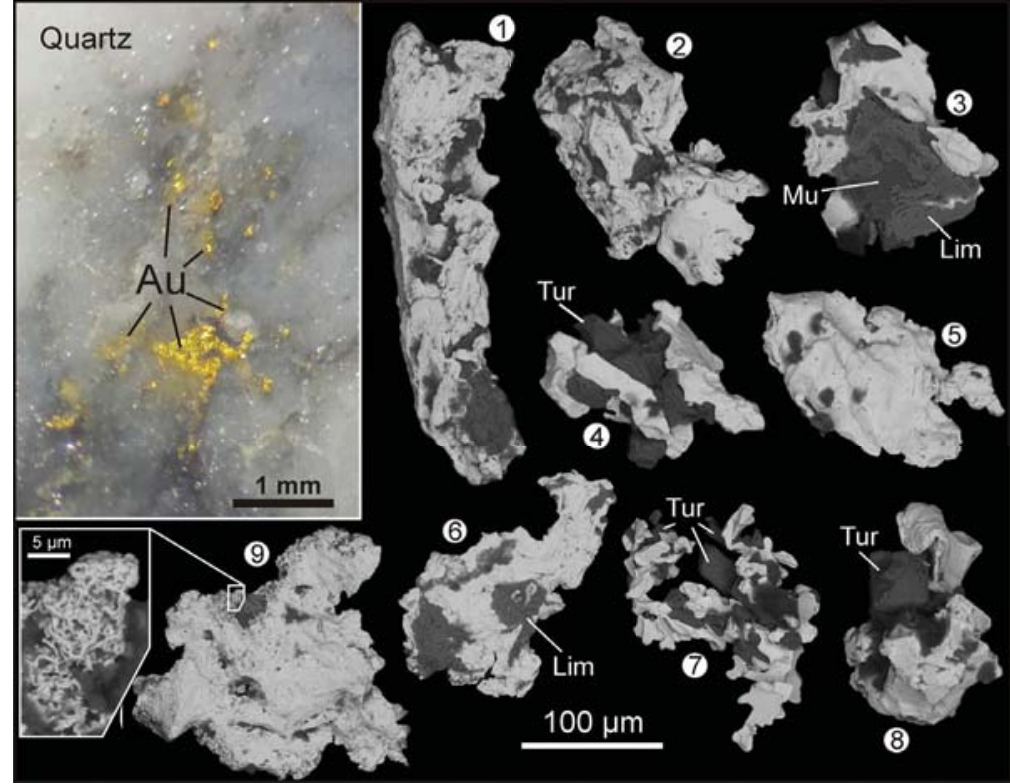

Fig. 4. Image of native gold in quartz string and submicroscopic image of surface of gold particle washed out from carbonaceous shale and residuum in Baikal site
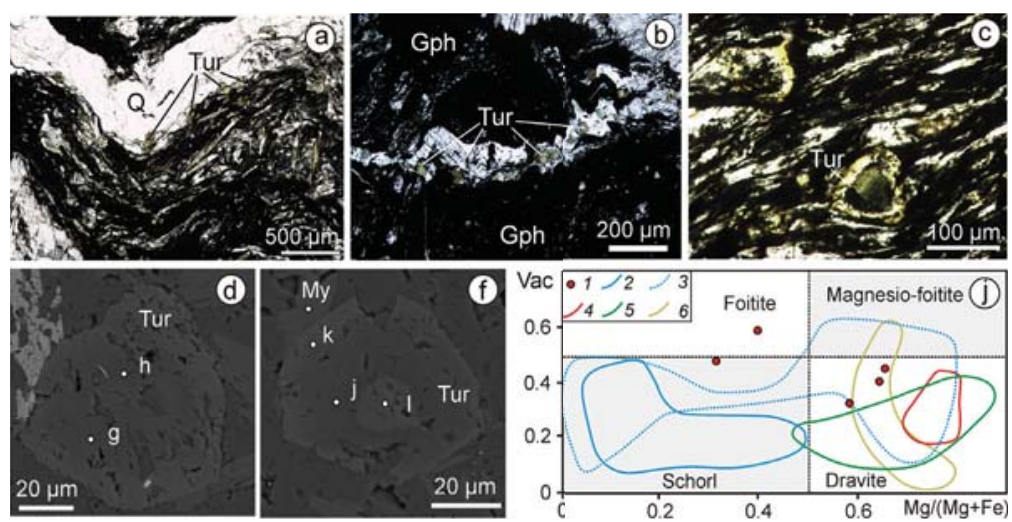

Fig. 5. Tourmaline mineralization in carbonaceous shale in Baikal site Tur - tourmaline; My - muscovite; Q - quartz; Gph - graphite; $a$ and $b$ - banded and curved structure of carbon-bearing quartz-micaceous shale; $c$ - zonal distribution of tourmaline with inclusions of carbonaceous substance; $d$ and $f$ - submicroscopic images of cross sections of tourmaline crystals and the test points (Table 2); $j$ - comparison of tourmaline compositions in different genesis deposits: 1 - points of tourmaline compositions in Baikal site; 2-6 fields of tourmaline compositions from 2, 3 - Hnilets tin deposit, Slovakia [18]: 2 - granite; 3 - enclosing metamorphic rocks; 4 - orogenic gold at Hatti, India [19]; 5 - Cu-Mo-Au-Te porphyry deposit Fakos in Greece [20]; 6 - gold-sulfide deposit Murtykty [22]

obtained 40 fine gold particles from $0.05 \times 0.1$ to $0.3 \times 0.1 \mathrm{~mm}$ in size. Furthermore, in a quartz string, we discovered a large gold cluster penetrated to a depth of $1.5 \mathrm{~cm}$ in the sample. Native gold has diverse shapes: platelike, isometric, aggregates and lamellas (see Fig. 4). Gold particles are often covered with colloform botryoidal crusts of limonite and with muscovite and tourmaline accretions. The microprobe analysis shows a uniform composition of elements (Table 5). Gold belongs to the high carat type (Au 90-96\%), and silver content 
Table 1. Mineral inclusions in carbonaceous shale in Baikal site

\begin{tabular}{|c|c|c|c|c|c|c|c|c|}
\hline Analysis & $S$ & $\mathrm{Fe}$ & Co & $\mathrm{Ni}$ & $\mathrm{Cu}$ & As & Total & Formula \\
\hline 1 & 34.64 & 30.5 & & & 36.15 & & 101.28 & $\mathrm{Fe}_{0.98} \mathrm{Cu}_{1.02} \mathrm{~S}_{1.94}$ \\
\hline 2 & 17.13 & 7.94 & 2.75 & 23.6 & 0.64 & 47.95 & 100.00 & $\mathrm{Ni}_{0.67} \mathrm{Fe}_{0.24} \mathrm{Co}_{0.08} \mathrm{Cu}_{0.02} \mathrm{As}_{1.07} \mathrm{~S}_{0.89}$ \\
\hline 3 & 16.54 & 8.73 & 1.49 & 24.77 & & 51.15 & 102.67 & $\mathrm{Ni}_{0.70} \mathrm{Fe}_{0.26} \mathrm{Co}_{0.04} \mathrm{As}_{1.13} \mathrm{~S}_{0.85}$ \\
\hline 4 & 17.76 & 4.71 & 21.16 & 8.88 & & 47.49 & 100.00 & $\mathrm{Co}_{0.60} \mathrm{Ni}_{0.25} \mathrm{Fe}_{0.14} \mathrm{As}_{1.07} \mathrm{~S}_{0.93}$ \\
\hline 5 & 17.74 & 6.33 & 19.14 & 9.44 & & 47.35 & 100.00 & $\mathrm{Co}_{0.54} \mathrm{Ni}_{0.27} \mathrm{Fe}_{0.19} \mathrm{As}_{1.06} \mathrm{~S}_{0.92}$ \\
\hline Analysis & $\mathrm{Ni}$ & $\mathrm{Au}$ & $\mathrm{Ag}$ & $\mathrm{Te}$ & $\mathrm{Pb}$ & $\mathrm{Bi}$ & Total & Formula \\
\hline 6 & & 94.74 & 5.26 & & & & 100.00 & $\mathrm{Au}_{0.91} \mathrm{Ag}_{0.09}$ \\
\hline 7 & & & 1.78 & 41.96 & 20.99 & 35.5 & 100.23 & $\left(\mathrm{Bi}_{1.93} \mathrm{~Pb}_{1.15} \mathrm{Ag}_{0.19}\right) \mathrm{Te}_{3.73}$ \\
\hline 8 & & & 1.83 & 43.32 & 18.23 & 36.62 & 100.00 & $\left(\mathrm{Bi}_{1.98} \mathrm{~Pb}_{0.99} \mathrm{Ag}_{0.19}\right) \mathrm{Te}_{3.84}$ \\
\hline 9 & & 36.95 & 9.64 & 48.07 & & 5.35 & 100.00 & $\left(\mathrm{Au}_{1.66} \mathrm{Ag}_{0.79}\right) \mathrm{Te}_{3.33} \mathrm{Bi}_{0.23}$ \\
\hline 10 & 19.58 & & & 80.20 & & & 99.77 & $\mathrm{Ni}_{1.06} \mathrm{Te}_{2.00}$ \\
\hline 11 & & & & 44.76 & 4.53 & 50.28 & 99.57 & $\mathrm{Bi}_{0.78} \mathrm{~Pb}_{0.07} \mathrm{Te}_{1.14}$ \\
\hline 12 & & 89.69 & 10.31 & & & & 100.00 & $\mathrm{Au}_{0.83} \mathrm{Ag}_{0.17}$ \\
\hline 13 & & 85.63 & 14.37 & & & & 100.00 & $\mathrm{Au}_{0.77} \mathrm{Ag}_{0.23}$ \\
\hline \multicolumn{9}{|c|}{$\begin{array}{l}\text { Comment: } 1 \text { - chalcopyrite (Ccp); } 2,3 \text { - gersdorffite (Grf); } 4,5 \text { - cobaltite (Cbt); } \\
\text { 6, 12, } 13 \text { - gold (Au); } 7,8 \text { - rucklidgeite (Rk); } 9 \text { - sylvanite (Silv); } 10 \text { - melonite (Mel); } \\
11 \text { - tellurobismuthite (BiTe); see positions of the test points in Fig. } 3 .\end{array}$} \\
\hline
\end{tabular}

Table 2. Chemical composition of tourmaline in carbonaceous shale in Baikal site

\begin{tabular}{|c|c|c|c|c|c|c|c|c|c|}
\hline Analysis & $\mathrm{Na}_{2} \mathrm{O}$ & $\mathrm{MgO}$ & $\mathrm{Al}_{2} \mathrm{O}_{3}$ & $\mathrm{SiO}_{2}$ & $\mathrm{CaO}$ & $\mathrm{TiO}_{2}$ & $\mathrm{FeO}$ & Total & Mineral \\
\hline$g$ & 2.08 & 5.29 & 33.76 & 37.64 & & 0.47 & 6.84 & 100.12 & Dravite \\
\hline $\mathrm{h}$ & 1.71 & 5.76 & 33.58 & 37.94 & 0.32 & 0.67 & 6.13 & 100.19 & Dravite \\
\hline $\mathrm{i}$ & 1.29 & 3.44 & 34.43 & 38.42 & & 0.21 & 9.28 & 101.24 & Foitite \\
\hline $\mathrm{j}$ & 1.46 & 6.07 & 34.31 & 37.57 & 0.50 & 0.57 & 5.72 & 100.41 & Dravite \\
\hline $\mathrm{k}$ & 1.34 & 2.89 & 32.86 & 36.66 & 0.46 & 1.07 & 10.92 & 99.99 & Schorl \\
\hline
\end{tabular}

Table 3. Float sampling results on $\mathrm{Au}$ $(g / t)$ in quartz veins and carbonaceous sediments in Baikal site

\begin{tabular}{|c|c|c|c|c|c|}
\hline $\begin{array}{c}\text { Test } \\
\text { No. }\end{array}$ & $\begin{array}{c}\text { Sample } \\
\text { No. }\end{array}$ & Au & $\begin{array}{c}\text { Test } \\
\text { No. }\end{array}$ & $\begin{array}{c}\text { Sample } \\
\text { No. }\end{array}$ & Au \\
\hline 1 & $\mathrm{km08s}$ & 0.15 & 12 & $\mathrm{km09s}$ & $\mathbf{0 . 5 5}$ \\
\hline 2 & $\mathrm{~km} 10 \mathrm{~s}$ & - & 13 & $\mathrm{km01s}$ & 0.28 \\
\hline 3 & $\mathrm{~km} 11 \mathrm{~g}$ & $\mathbf{3 . 5 0}$ & 14 & $\mathrm{km02s}$ & 0.10 \\
\hline 4 & $\mathrm{~km} 12 \mathrm{~s}$ & - & 15 & $\mathrm{km03s}$ & $\mathbf{0 . 3 4}$ \\
\hline 5 & $\mathrm{km01g}$ & $\mathbf{6 . 5 0}$ & 16 & $\mathrm{km04s}$ & 0.15 \\
\hline 6 & $\mathrm{km04s}$ & - & 17 & $\mathrm{~km} 08 \mathrm{~s}$ & 0.16 \\
\hline 7 & $\mathrm{km04g}$ & $\mathbf{0 . 6 4}$ & 18 & $\mathrm{~km} 09 \mathrm{~s}$ & 0.20 \\
\hline 8 & $\mathrm{~km} 10 \mathrm{~g}$ & $\mathbf{0 . 7 9}$ & 19 & $\mathrm{~km} 10 \mathrm{~s}$ & 0.12 \\
\hline 9 & $\mathrm{~km} 12 \mathrm{~g}$ & $\mathbf{0 . 3 2}$ & 20 & $\mathrm{~km} 11 \mathrm{~s}$ & 0.11 \\
\hline 10 & $\mathrm{~km} 13 \mathrm{~g}$ & $\mathbf{0 . 5 7}$ & 21 & $\mathrm{~km} 12 \mathrm{~s}$ & 0.17 \\
\hline 11 & $\mathrm{~km} 14 \mathrm{~s}$ & 0.15 & 22 & $\mathrm{~km} 13 \mathrm{~s}$ & 0.13 \\
\hline
\end{tabular}

Comment: 1 -4 - quartz veins; 5-22 -

black shale; 5-10 - quartzy and

ferruginous shale; $11-22$ - slightly

altered carbonaceous shale; dash - gold content is below the test sensitivity. is $4-9 \%$. It is interesting that secondary gold redeposition is sometimes observed in the form of small spongy high-grade nodules (Fig. 4, gold particle No. 9) typical of hypergenesis zone.

\section{Conclusions}

Thus, the studies of black shale sediments in Baikal site show that the sediments belong to the carbonaceous type, as well as to terrigene-carbonaceous and silica-carbonaceous formations. Carbonaceous substance represented by slightly metamorphized sapropel sedimentation-diagenetic and metamorphic graphite has a biogenic nature and experiences metamorphism in the condition of green shale facies.

It is found that gold ore mineralization within the study site adjoins mostly bands of quartzo-micaceous-tourmaline metasomatically altered carbonaceous shale. Gold is finely dispersed and is connected with two basic mineral associations: gold-bismuth-telluride and native gold intergrown with tourmaline. By chemical composition, tourmaline belongs to dravite and foitite, and is similar to the same minerals in orogenic gold and gold-sulfide deposits. Tight intergrowth of gold and fine needle-like tourmaline points at their synchronous

\section{Table 4. Float sampling results on $\mathrm{Au}$ and $\mathrm{Ag}(\mathrm{g} / \mathrm{t})$ in section $\mathrm{A}-\mathrm{B}$}

\begin{tabular}{|c|c|c|c|c|c|c|c|c|c|c|c|}
\hline No. & Sample No. & $\mathrm{Au}$ & $\mathrm{Ag}$ & No. & Sample No. & $\mathrm{Au}$ & $\mathrm{Ag}$ & No. & Sample No. & $\mathrm{Au}$ & $\mathrm{Ag}$ \\
\hline 1 & $\mathrm{~km} 85 \mathrm{~g}-1.0$ & 0.09 & $\mathbf{3 . 4}$ & 10 & $\mathrm{~km} 85 \mathrm{~s}-80.4$ & 0.18 & 2.0 & 19 & $\mathrm{~km} 85 \mathrm{~s}-29.0$ & 0.08 & 1.4 \\
\hline 2 & $\mathrm{~km} 85 \mathrm{~g}-4.0$ & - & $\mathbf{3 . 2}$ & 11 & $\mathrm{~km} 85 \mathrm{~s}-100.0$ & - & 1.8 & 20 & $\mathrm{~km} 85 \mathrm{~s}-30.0$ & - & 1.4 \\
\hline 3 & $\mathrm{~km} 85 \mathrm{~g}-11.4$ & 0.15 & $\mathbf{3 . 4}$ & 12 & $\mathrm{~km} 85 \mathrm{~s}-105.0$ & 0.09 & 2.2 & 21 & $\mathrm{~km} 85 \mathrm{~s}-40.0$ & 0.09 & 1.0 \\
\hline 4 & $\mathrm{~km} 85 \mathrm{~g}-35.6$ & 0.15 & $\mathbf{7 . 2}$ & 13 & $\mathrm{~km} 85 \mathrm{~s}-21.1$ & $\mathbf{0 . 4 4}$ & 1.8 & 22 & $\mathrm{~km} 85 \mathrm{~s}-66.0$ & 0.10 & 2.0 \\
\hline 5 & $\mathrm{~km} 85 \mathrm{~g}-42.8$ & 0.06 & $\mathbf{3 . 4}$ & 14 & $\mathrm{~km} 85 \mathrm{~g}-29.2$ & 0.12 & $\mathbf{3 . 0}$ & 23 & $\mathrm{~km} 85 \mathrm{~s}-75.0$ & 0.16 & 1.4 \\
\hline 6 & $\mathrm{~km} 85 \mathrm{~g}-48.3$ & 0.06 & 2.6 & 15 & $\mathrm{~km} 85 \mathrm{~s}-55.0$ & 0.09 & 2.6 & 24 & $\mathrm{~km} 85 \mathrm{~s}-90.0$ & 0.09 & 0.8 \\
\hline 7 & $\mathrm{~km} 85 \mathrm{~g}-60.3$ & 0.08 & $\mathbf{4 . 2}$ & 16 & $\mathrm{~km} 85 \mathrm{~g}-96.3$ & 0.09 & 1.8 & 25 & $\mathrm{~km} 85 \mathrm{~s}-70.0$ & $\mathbf{0 . 3 5}$ & 2.4 \\
\hline 8 & $\mathrm{~km} 85 \mathrm{~s}-67.7$ & 0.15 & 1.6 & 17 & $\mathrm{~km} 85 \mathrm{~g}-102.8$ & 0.08 & 2.6 & 26 & $\mathrm{~km} 85 \mathrm{~g}-86.5$ & 0.08 & $\mathbf{3 . 4}$ \\
\hline 9 & $\mathrm{~km} 85 \mathrm{~g}-72.0$ & 0.07 & $\mathbf{7 . 6}$ & 18 & $\mathrm{~km} 85 \mathrm{~s}-25.0$ & 0.06 & 2.2 & & & & \\
\hline $\begin{array}{l}\text { Comment: } 1-12-9 \\
\text { quartz; } 25 \text { - fungous and ferruginous veined quartz; } 26-\text { brightened ferruginous grey }\end{array}$ \\
carbonaceous shale; dash-gold content is below the test sensitivity. \\
\hline
\end{tabular}

Table 5. Element analysis of gold particles from Baikal site

\begin{tabular}{|c|c|c|c|c|}
\hline $\begin{array}{c}\text { Gold } \\
\text { particle } \\
\text { No. }\end{array}$ & $\mathrm{Au}$ & $\mathrm{Ag}$ & Total & Formula \\
\hline 1 & 93.88 & 6.12 & 100 & Au0.89Ag0.11 \\
\hline 2 & 95.73 & 4.27 & 100 & Au0.92Ag0.08 \\
\hline 3 & 94.74 & 5.26 & 100 & Au0.91Ag0.09 \\
\hline 4 & 95.73 & 4.27 & 100 & Au0.92Ag0.08 \\
\hline 5 & 94.04 & 5.96 & 100 & Au0.90Ag0.10 \\
\hline 6 & 90.88 & 9.12 & 100 & Au0.85Ag0.15 \\
\hline 7 & 94.55 & 5.45 & 100 & Au0.90Ag0.10 \\
\hline Comment: see numbers of particles in Fig. 2. \\
\hline
\end{tabular}


formation and enables assessing Baikal site as quartzo-tourmaline gold ore formation. Panning assaying of all rock varieties showed commercial gold content to $6.5 \mathrm{~g} / \mathrm{t}$ and stable high silver content to $7.6 \mathrm{~g} / \mathrm{t}$. According to the analysis of gold particles washed out of quartz veins and carbonaceous shale, this gold belongs to the high carat type. In the zone of hypergenesis, secondary redeposition of gold takes places in the form of spongy high-grade aggregates.

\section{Funding and acknowledgements}

The study was carried out under State Contract Topic No. 0246-2019-0078, the microprobe analyses were performed under State-Financed Topic No. AAAA-A19-119072390050-9 and were supported by Orenburgneft JSC in the framework of a corporate grant, 2019-2020.

The authors are extremely grateful to S. A. Yagudina, T. I. Chernikova and I. V. Smoleva for the analysis execution, to E. O. Kalistratova for the help in heavy concentrate description, as well as to R. S. Kisil and V. S. Panteleev for the assistance in field works.

\section{References}

1. Groves D. I., Goldfarb R. J., Robert F., Hart C. J. R. Gold Deposits in Metamorphic Belts: Overview of Current Understanding, Outstanding Problems, Future Research, and Exploration Significance. Economic Geology. 2003. Vol. 98, No. 1. pp. 1-29.

2. Arifulov Ch. Kh. Black shale gold deposits of various geological conditions. Ores and metals. 2005. No. 2. pp. 9-19.

3. Large R. R., Bull S. W., Maslennikov V. V. A carbonaceous sedimentary source-rock model for carlin type and orogenic gold deposits. Economic Geology. 2011. Vol. 106, No. 3. pp. 331358.

4. Shumilova T. G., Shevchuk S. S., Isayenko S. I. Metal concentrations and carbonaceous matter in the black shale type rocks of the Urals. Doklady Earth Sciences. 2016. Vol. 469, No. 1. pp. 695-698.

5. Ivanov A. I. The role played by metamorphic transformation conditions of carbonaceous carbonate-terrigene deposits for gold mineralization formation at various stages of collisional epoch of Baikal-patom metallogenic province development. Otechestvennaya geologiya. 2017. No. 4. pp. 3-23.

6. Majumdar S., Singh S., Sahoo P. R. Characterization of organic matter and its implications for pyrite hosted refractory gold mineralization along the South Purulia Shear Zone, eastern India. Ore Geology Reviews. 2020. Vol. 124.103584. DOI: 10.1016/j.oregeorev. 2020.103584

7. Znamensky S. E., Znamenskaya N. M. Classification of gold deposits of the eastern slope of the Southern Urals. Geological collection. 2009. No. 8. pp. 177-186.

8. Snachev A. V., Puchkov V. N. First findings of palladium-goldREE ore mineralization in precambrian carbonaceous shales on the western slope of the Southern Urals. Doklady Earth Sciences. 2010. Vol. 433, No. 1. pp. 866-869. DOI: 10.1134/ S1028334X10070044

9. Gadd M. G., Peter J. M., Jackson S. E., Zhaoping Yang, Petts D. Platinum, Pd, Mo, Au and Re deportment in hyperenriched black shale Ni-Zn-Mo-PGE mineralization, Peel River, Yukon, Canada. Ore Geology Reviews. 2019. Vol. 107, pp. 600-614.

10. Snachev A. V., Latypov F. F., Snachev V. I., Rassomakhin M. A., Koschug D. G., Vyatkin S. V. Siraturskoe gold deposit in a crystal of the ophiolite association (South Urals). Bulletin of Moscow University. Ser. 4. Moscow: Geology. 2020. No. 5. pp. 64-70.

11. Bilibina T. V., Bogdanov Yu. V. On the prospects of gold bearing in the Mugodzhar region. Geology of ore deposits. 1959. No. 5. pp. 104-111.

12. Albov M. N. The secondary zoning of gold deposits of the Urals. Moscow: Gosgeoltekhizdat, 1960. 215 p.

13. Voin M. I. Features of the structure and mineralization of the Kumak ore field and the methodology for the allocation of enriched intervals in the mineralized zones of crushing. News of universities. Geology and exploration. 1966. Vol. 11, pp. 77-86.

14. Kolomoets A. V., Snachev A. V. Rassomakhin M. A. Gold-tourmaline mineralization in carbonaceous shales of the Kumak deposit (South Ural). Gornyi Zhurnal. 2020. Vol. 12. pp. 11-15. DOI: $10.17580 /$ gzh.2020.12.02

15. Kolomoets A., Snachev A., Smoleva I. Carbonaceous matter in black-shale deposits of the Bredy Formation (Southern Urals). Kazan Golovkinsky Young Scientists "Stratigraphic Meeting 2020 and Young Scientists Summer School". 2020. Vol. 8. p. 37.

16. London D., Morgan G., Wolf M. Boron in granitic rocks and their contact aureoles. Reviews in Mineralogy. 1996. Vol. 33. pp. 299-330.

17. Baksheev I., Prokof'ev V. Y., Zaraisky G., Chitalin A., Yapaskurt V. et al. Tourmaline as a prospecting guide for the porphyry style deposits. European Journal of Mineralogy. 2012. Vol. 24, No. 6. pp. 957-979.

18. Jiang S.-J., Radvanec M., Nakamura E., Palmer M., Kobayashi K., Zhao H.-X., Zhao K.-D. Chemical and boron isotopic variations of tourmaline in the Hnilec granite-related hydrothermal system. Slovakia: Constraints on magmatic and metamorphic fluid evolution. Lithos. 2008. Vol. 106, No. 1. pp. 1-11.

19. Hazarika P., Mishra B. Tourmaline as fluid source indicator in the late Archean Hutti orogenic gold deposit. Mineral Resources in a Sustainable World: $13^{\text {th }}$ SGA biennial meeting. Nancy. 2015. pp. 465-467.

20. Voudouris P., Baksheev I. A., Mavrogonatos C., Spry P. G., Djiba A. et al. Tourmaline from the Fakos porphyry-epithermal Cu-Mo-Au-Te prospect, Limnos island, Greece: mineralchemistry and genetic implications. Bulletin of the Geological Society of Greece. 2019. Vol. 7. pp. 329-330.

21. Rassomakhin M. A., Belogub E. V., Novoselov K. A., Khvorov $P$. V. Tourmaline from late quartz veins of the Murtykty gold deposit, South Ural, Bashkortostan. Mineralogy. 2020. Vol. 6, No. 1. pp. 69-83. DOI: 10.35597/2313-545X-2020-6-1-7

22. Serdyuchenko D. P. On some boron-rich sedimentary-metamorphic facies. Reports of the Academy of Sciences of the USSR. Moscow : Publishing house of the Academy of Science of the USSR, 1955. Vol. 102, No. 4.

23. Cabral A. R., Tupinambá M., Zeh A., Lehmann B., Wiedenbeck M., Brauns M., Kwitko-Ribeiro R. Platiniferous goldtourmaline aggregates in the gold-palladium belt of Minas Gerais, Brazil : implications for regional boron metasomatism. Mineralogy and Petrology. 2017. Vol. 111, No. 6. pp. 807-819.

24. Sokol E. V., Kokh S. N., Kozmenko O. A., Lavrushin V. Yu, Belogub E. V. et al. Boron in an onshore mud volcanic environment: Case-study from the Kerch Peninsula, the Caucasus continental collision zone. Chemical Geology. 2019. Vol. 525, pp. 58-81. 